\title{
Infectious SARS-CoV-2 Is Emitted in Aerosol Particles
}

\author{
Seth A. Hawks, ${ }^{a}$ (D) Aaron J. Prussin II, ${ }^{b}$ Sarah C. Kuchinsky, Jin Pan, ${ }^{b}$ Linsey C. Marr, ${ }^{b}$ (D) Nisha K. Duggal \\ aDepartment of Biomedical Sciences and Pathobiology, Virginia-Maryland College of Veterinary Medicine, Virginia Polytechnic Institute and State University, Blacksburg, \\ Virginia, USA \\ bDepartment of Civil and Environmental Engineering, Virginia Polytechnic Institute and State University, Blacksburg, Virginia, USA
}

\begin{abstract}
Respiratory viruses such as SARS-CoV-2 are transmitted in respiratory droplets and aerosol particles, which are released during talking, breathing, coughing, and sneezing. Noncontact transmission of SARS-CoV-2 has been demonstrated, suggesting transmission via virus carried through the air. Here, we demonstrate that golden Syrian hamsters produce infectious SARS-CoV-2 in aerosol particles prior to and concurrent with the onset of mild clinical signs of disease. The average emission rate in this study was 25 infectious virions/hour on days 1 and 2 postinoculation, with average viral RNA levels 200-fold higher than infectious virus in aerosol particles. The majority of virus was contained within particles $<5 \mu \mathrm{m}$ in size. Thus, we provide direct evidence that, in hamsters, SARS-CoV-2 is an airborne virus.
\end{abstract}

IMPORTANCE SARS-CoV-2 is a respiratory virus and has been isolated from the air near COVID-19 patients. Here, using a hamster model of infection, we demonstrate that SARS-CoV-2 is emitted in aerosol particles prior to and concurrent with the onset of mild disease. Virus is contained primarily within aerosol particles $<5 \mu \mathrm{m}$ in size, which can remain airborne and be inhaled. These findings indicate that SARSCoV-2 is an airborne virus and support the use of ventilation to reduce SARS-CoV-2 transmission.

KEYWORDS animal models, coronavirus, transmission

ARS-CoV-2 is a respiratory virus that has caused more than 225 million cases and 4.6 million deaths as of September 2021 (https://covid19.who.int/). The virus is expelled from infected individuals in respiratory droplets that are produced during coughing, sneezing, talking, and breathing. The droplets can vary widely in size from less than $1 \mu \mathrm{m}$ to about 1,000 $\mu \mathrm{m}$, and the smaller ones may evaporate to less than half their initial diameter into a semisolid or solid particle $(1,2)$. Here, we refer to those smaller than $100 \mu \mathrm{m}$ (3) as "aerosol particles" or simply "particles"; technically, an "aerosol" is a suspension of solid or liquid particles in a gas (4). Size is an important determinant of how droplets and particles travel through the air, so it significantly impacts transmission risk and mode. Those smaller than $10 \mu \mathrm{m}$ remain suspended in air for many minutes to hours, during which they can travel long distances; this does not rule out their potential to transmit at close range, too $(5,6)$.

Infectious SARS-CoV-2 has been cultured from airborne particles sampled near COVID-19 patients $(7,8)$. SARS-CoV-2 has also been isolated from particles $<1 \mu \mathrm{m}$ within a car driven by a COVID-19 patient with mild illness (9). The collection of exhaled breath is a noninvasive sampling method that has been used to assess the airborne transmission potential of respiratory viruses, including seasonal human coronaviruses, influenza viruses, and rhinoviruses (10-13). For COVID-19 patients, SARS-CoV-2 RNA was detected in exhaled breath $(14,15)$. In nonhuman primates, SARS-CoV-2 RNA has also been detected in aerosol particles collected from inoculated animals $(16,17)$.
Citation Hawks SA, Prussin AJ, II, Kuchinsky SC, Pan J, Marr LC, Duggal NK. 2021. Infectious SARS-CoV-2 is emitted in aerosol particles. mBio 12:e2527-21. https://doi.org/10.1128/ mBio.02527-21.

Editor John A. Lednicky, University of Florida Copyright $\odot 2021$ Hawks et al. This is an openaccess article distributed under the terms of the Creative Commons Attribution 4.0 International license. Address correspondence to Nisha K. Duggal, nduggal@vt.edu.

Received 23 August 2021

Accepted 23 September 2021

Published 19 October 2021 
A.

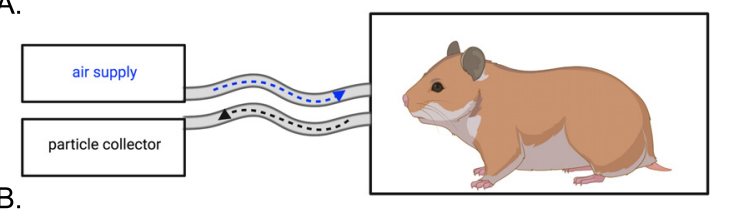

B.

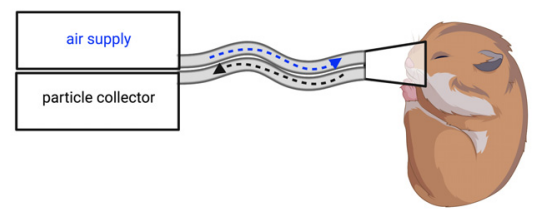

C.

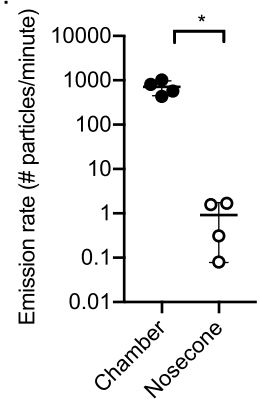

FIG 1 Air sampling methods. Aerosol particles were collected using a condensation sampler or an aerodynamic particle sizer. (A) Air was collected from awake hamsters within a sealed 2-liter chamber. (B) Air was collected from anesthetized hamsters using a nosecone. (C) Aerosol particle emission rate from uninfected hamsters $(n=4)$ in the chamber (filled circles) or by nosecone (open circles). ${ }^{*}$, $P<0.05$. This figure was created with BioRender.com.

Hamsters are a naturally susceptible animal model for SARS-CoV-2 transmission and develop few clinical signs of disease (18-23). Importantly, inoculated hamsters have been shown to transmit SARS-CoV-2 to naive hamsters via noncontact transmission $(18,19,23)$, suggesting SARS-CoV-2 may be transmitted between animals via aerosol particles released during breathing. However, infectious SARS-CoV-2 has not yet been successfully cultured from aerosol particles released from infected animals.

In this study, we sought to determine the shedding kinetics of infectious SAS-CoV-2 in aerosol particles. We found that hamsters inoculated with SARS-CoV-2 emit infectious SARS-CoV-2 into the air prior to and concurrent with the onset of mild clinical signs of disease. Viral titers decreased quickly over time, whereas viral RNA was detected in particles collected from the air for many days postinoculation. We also found that particles $<5 \mu \mathrm{m}$ contain the majority of airborne virus.

\section{RESULTS}

Particle generation by hamsters. To test whether inoculated animals shed SARSCoV-2 in aerosol particles, we established two sampling methods for hamsters. In the first method, animals were allowed to move freely within an empty 2-liter chamber (Fig. 1A). In the second method, animals were anesthetized, and a nosecone was placed over the nose and mouth (Fig. 1B). Attempts were made to restrain hamsters for the nosecone sampling without anesthesia but were unsuccessful. Particles were sampled via an outlet port from the chamber or nosecone.

We measured particles produced by uninfected hamsters and calculated the emission rate. Using the chamber, we found an average of 700 particles emitted per minute per hamster (Fig. 1C), with $99.9 \%$ of them $<10 \mu \mathrm{m}$ in size (Fig. S1 in the supplemental material). Using the nosecone, we found an average of 1 particle emitted per minute per hamster, which was significantly fewer than measured using the chamber approach $(P<0.05)$. The size distribution was similar in both cases, with very small particles being the most abundant.

Infectious SARS-CoV-2 is emitted in aerosol particles. In two independent experiments, hamsters were inoculated intranasally with SARS-CoV-2 strain USA-WA1/2020. Mild weight loss occurred 2 through 5 days postinoculation (dpi) (Fig. 2A). Oral swabs and nasal washes were collected daily. Virus peaked $1 \mathrm{dpi}$ in the oral swabs at $3.5-\log _{10}$ PFU/swab and 2 dpi in the nasal washes at 3.9- $\log _{10}$ PFU/wash (Fig. $2 \mathrm{~B}$ and C). Significantly higher viral titers were observed in nasal washes from males than females 1 dpi, with a 5,000-fold difference $(P<0.001)$ (Fig. S2C). Viral titers for females peaked 1 day later than males, which was consistent between independent experiments. Viral titers decreased over time, with infectious virus below the limit of detection by 5 dpi for most animals. Samples were tested for SARS-CoV-2 RNA, which was detectable through 10 dpi (Fig. 2E and F). Sex-specific differences were not observed for viral RNA levels (Fig. S2E and F). 
A.

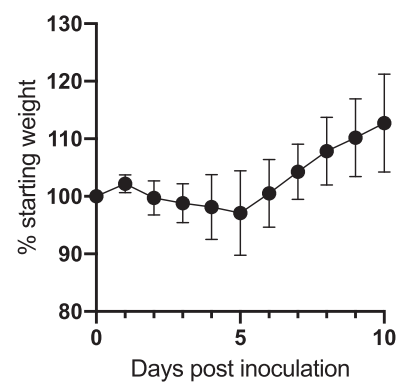

B.

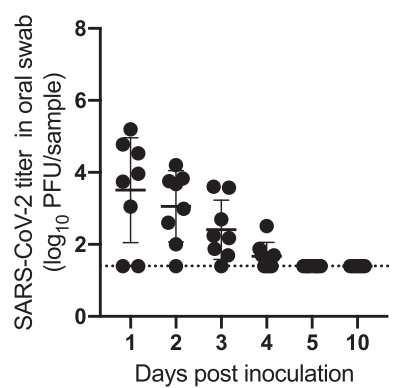

E.

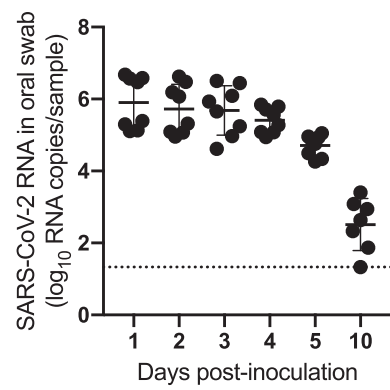

C.

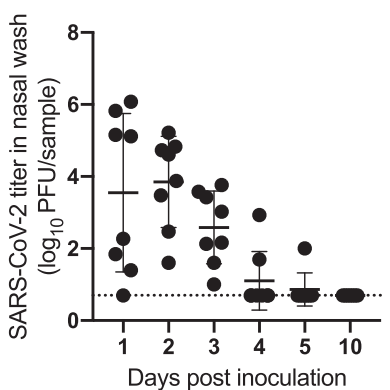

F.

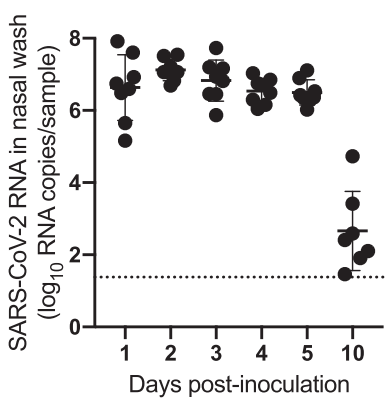

D.

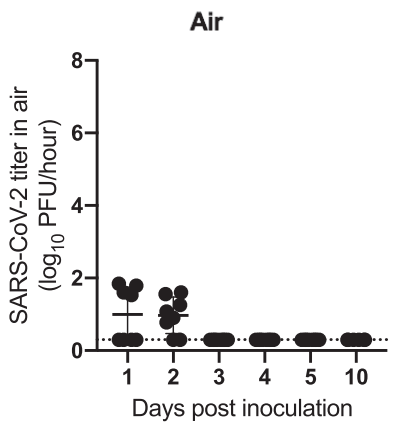

G.

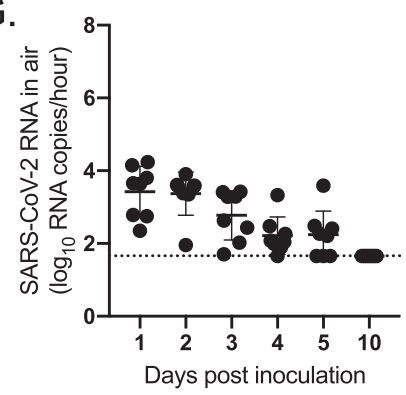

FIG 2 Emission of SARS-CoV-2 in aerosol particles. Hamsters ( $n=8$ ) were inoculated intranasally with SARS-CoV-2. (A) Percent starting weight; (B) viral titers in oral swabs; (C) viral titers in nasal washes; (D) viral titers in air samples; (E) viral RNA levels in oral swabs; (F) viral RNA levels in nasal washes; (G) viral RNA levels in air samples. Dashed line represents limit of detection.

Air samples were collected daily using the chamber approach for $1 \mathrm{~h}$ with a condensation sampler, which maintains viral infectivity (7). Infectious virus was detected in particles collected 1 and 2 dpi, with a mean emission rate of $1.4-\log _{10}$ PFU/hour (Fig. 2D). Significantly greater infectious viral titers were detected in air samples from males than females $1 \mathrm{dpi}(P<0.01)$ (Fig. S2D). A majority $(75 \%)$ of inoculated animals released detectable levels of virus in the air $2 \mathrm{dpi}$, and emission rates ranged from 0.9to $1.8-\log _{10}$ PFU/hour. Infectious virus was below the limit of detection in samples collected after 2 dpi. Air samples were also tested for viral RNA; viral RNA was detected through $5 \mathrm{dpi}$, with levels below the limit of detection by $10 \mathrm{dpi}$ (Fig. 2G). Sex-specific differences were not observed for viral RNA levels in the air (Fig. S2G). For samples with detectable infectious virus, the RNA levels were approximately 200-fold higher than PFU levels on 1 and 2 dpi. Together, these data show that infectious SARS-CoV-2 is emitted in aerosol particles early in infection, prior to and concurrent with the onset of mild clinical signs of disease.

Particles $<\mathbf{5} \boldsymbol{\mu m}$ contain infectious SARS-CoV-2. Once we established the window of time postinoculation when infectious virus was detected in aerosol particles (1 to $2 \mathrm{dpi}$ ), we inoculated 8 additional hamsters in order to test whether small particles contain infectious SARS-CoV-2. Here, we shortened the air sampling time to $30 \mathrm{~min}$. Male hamsters were used, as virus was more readily detected in their air samples compared to females' air samples. To test whether the virus detected in the air was residual inoculum, we collected an air sample at $4 \mathrm{~h}$ postinoculation using the chamber; no virus was detected (Fig. 3A). Then, we collected air samples 1 and 2 dpi in the chamber with and without a cyclone separator, which removed particles $>5 \mu \mathrm{m}$, placed upstream of the condensation sampler. We detected similar titers in samples collected with and without the cyclone separator, with no statistical significance in the difference in mean titers on $1 \mathrm{dpi}(P=0.34)$ or $2 \mathrm{dpi}(P=0.37)$, indicating that size restriction of particles did not alter the amount of virus detected (Fig. 3A). To test whether SARS-CoV-2 was detectable in the breath, we anesthetized the hamsters and collected their breath from the nosecone for $1 \mathrm{~h}$. Infectious virus was not detectable. However, very few total particles were collected with this method compared to the chamber method (Fig. 1C). 


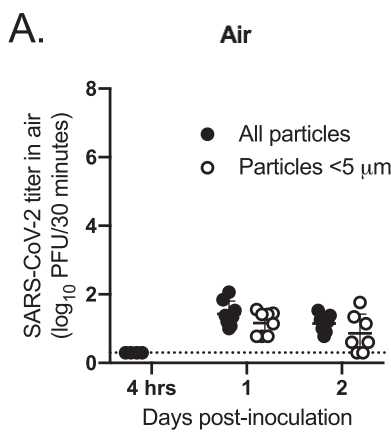

D.

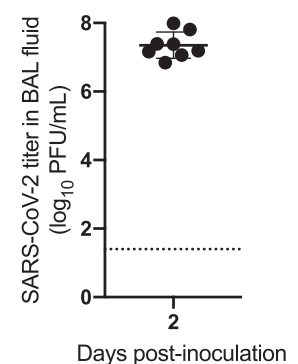

E.
B.

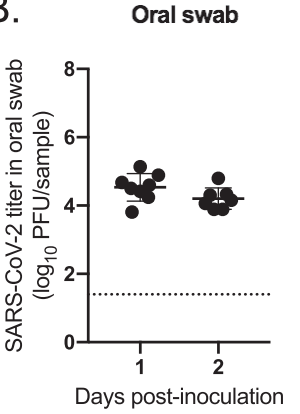

C. Nasal wash

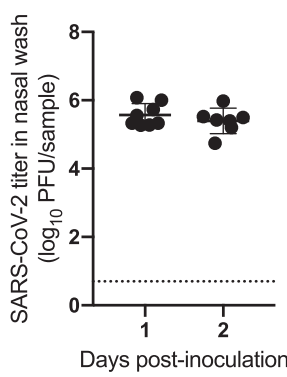

Fur swab

F.

Rectal swab
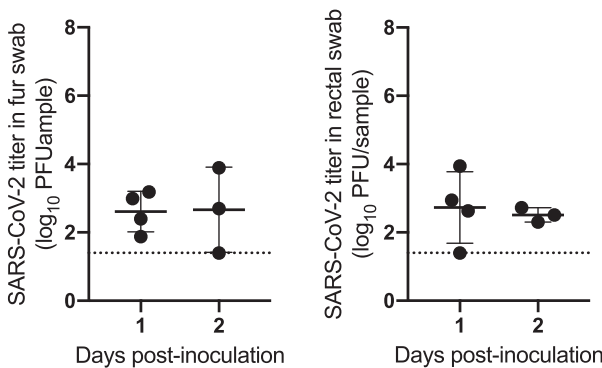

FIG 3 Aerosol particles $<5 \mu \mathrm{m}$ contain SARS-CoV-2. Hamsters $(n=8)$ were inoculated intranasally with SARS-CoV-2. (A) Viral titers in total particles (filled circles) or those $<5 \mu \mathrm{m}$ (open circles); (B) viral titers in oral swabs; $(C)$ viral titers in nasal washes; (D) viral titers in BAL fluid; (E) viral titers in fur swabs; (F) viral titers in rectal swabs. Dashed line represents limit of detection.

High levels of virus were detectable in oral swabs, nasal washes, and bronchoalveolar lavage (BAL) fluid collected from the animals (Fig. 3B to D). A low level of virus was detected in fur and rectal swabs taken from the animals, which indicates that some of the airborne virus detected in the chamber could be resuspended from the body (Fig. 3E and F). Together, these results indicate that SARS-CoV-2 is emitted primarily in particles $<5 \mu \mathrm{m}$.

\section{DISCUSSION}

In this study, we found that hamsters emitted infectious SARS-CoV-2 in particles primarily $<5 \mu \mathrm{m}$ in size prior to or concurrent with mild clinical disease, with an emission rate of 1.4- $\log _{10}$ PFU/hour (Fig. 2 and 3). SARS-CoV-2 viral RNA was detected in aerosol particles and the upper respiratory tract for a longer duration than infectious virus. The upper respiratory tract (nasal wash) and lower respiratory tract (BAL fluid and lung tissue) contained high titers of virus, suggesting that the virus isolated from the air was primarily derived from the breath. However, we found that the fur was contaminated with low levels of infectious virus, indicating that virus resuspended from the fur may also be a mechanism of SARS-CoV-2 emission into the air.

Particles $<5 \mu \mathrm{m}$ in size can remain airborne and be inhaled. Thus, our results suggest that airborne transmission is likely a major driver of SARS-CoV-2 transmission. Our studies support reports of infectious SARS-CoV-2 collected in the air near COVID-19 patients $(7,9)$ and in their exhaled breath $(24)$, as well as studies showing noncontact transmission of SARS-CoV-2 between ferrets and between hamsters $(18,19,23)$, including one study that demonstrated transmission over a 1-m distance (25). One previous study has been unable to culture virus in exhaled breath from COVID-19 patients (26), which could be due to unknown or late collection times postonset of disease. Another study was unable to culture virus from aerosol particles collected from nonhuman primates (17), possibly due to reliance on equipment and buffers that do not maintain viral infectivity. Our results support the idea that transmission is likely to occur prior to or concurrent with symptom onset or in the absence of severe clinical disease, 
supporting studies that have found that asymptomatic infection is a major driver of community transmission $(27,28)$. Identifying the modes of SARS-CoV-2 transmission is critical to designing interventions to effectively prevent transmission, and our results support the use of masks and ventilation to reduce SARS-CoV-2 transmission.

This study was limited by our inability to collect respiratory particles directly from the hamsters. We were unable to detect infectious virus directly from the breath when anesthetized; however, anesthesia decreases the breath rate of hamsters (29), and we detected 700-fold fewer aerosol particles with this method (Fig. 1). Thus, given the detection of infectious virus on the fur, we cannot exclude that virus resuspended from the fur during movement may have contributed to the particles that we detected using the chamber method. Movement in guinea pigs has been shown to increase influenza particles in the air by increasing the resuspension of dust particles from the body (30). The contribution of resuspended particles to SARS-CoV-2 airborne transmission has not been studied.

In this study, we detected a delay in infectious virus emission in female hamsters compared to male hamsters. Sex-specific differences in COVID-19 disease severity are widely reported, with more severe disease in men (31; https://globalhealth5050.org/ the-sex-gender-and-covid-19-project). It is unclear whether these sex-specific differences in infectious viral titers in nasal washes and air samples are relevant to human transmission. Lower cellular levels of a factor required for infection, such as ACE2 (32), may lead to lower viral emission in female hamsters. Interestingly, viral RNA levels in nasal washes and air samples were not significantly different between male and female hamsters. Thus, a factor that alters immune responses and is more highly expressed in females, such as estrogen (33), may enhance the release of defective virions. If the sex difference is only observed with infectious virus, rather than viral RNA, many studies may miss sex differences in viral titers, leading to the underestimation of differences in viral transmission potential between sexes. Sex-specific differences in infectious viral titers have not been observed by other groups, but differences in timing of samples collected may be relevant, as the largest difference was observed on $1 \mathrm{dpi}$ in this study, which was not tested in other studies $(34,35)$.

Public health agencies have recently begun describing SARS-CoV-2 as an airborne virus. Here, we show that infectious virus is indeed culturable from the air early after infection, with the majority of particles containing infectious virus $<5 \mu \mathrm{m}$ in size. This suggests that SARS-CoV-2 may be maintained in the air for hours and over larger distances than previously recognized, with ventilation being an important tool for preventing transmission. Future studies will be critical for establishing the transmission potential of aerosol particles containing SARS-CoV-2.

\section{MATERIALS AND METHODS}

Ethics statement. All animal experiments were approved by the Institutional Biosafety Committee and Institutional Animal Care and Use Committee at Virginia Polytechnic Institute and State University (IACUC protocol 20-184).

Viruses and cell lines. Inoculations were performed using SARS-CoV-2 strain USA-WA1/2020 (BEI Resources, NIAID, NIH; NR-52281), which was passaged once in Vero E6 cells followed by once in Vero cells upon receipt. Briefly, cells at approximately $80 \%$ confluence were inoculated with SARS-CoV-2, and supernatant was harvested when cytopathic effect (CPE) was present. Cells were cultivated in Dulbecco's modified Eagle medium (DMEM) (Corning; product no. 10-017-CV) containing 5\% gammairradiated fetal bovine serum (FBS) (VWR; catalog no. 97068-086), 100 units $/ \mathrm{ml}$ penicillin, and $100 \mu \mathrm{g} / \mathrm{ml}$ streptomycin (Gibco; catalog no. 15140122) and maintained at $37^{\circ} \mathrm{C}$ and $5 \% \mathrm{CO}_{2}$. All experiments involving infectious SARS-CoV-2 were performed in biosafety level 3 (BSL3) containment, which includes class II $A 2$ biosafety cabinets (BSC) and powered air-purifying respirators.

Animal studies. All animal studies were performed in two independent experiments, with all work performed in AAALAC-accredited animal BSL3 (ABSL3) facilities under an approved IACUC protocol. The hamsters (Mesocricetus auratus) were sourced from an approved commercial vendor, Envigo (Indianapolis, IN). Animals had health reports that indicated there was no evidence of any underlying pathogens. Hamsters were housed in biocontainment caging on individually ventilated caging (IVC) racks manufactured by Allentown, Inc. and were provided food and water ad libitum. Hamsters received Teklad diet formulation 2918, a natural ingredient, irradiated feed (6\% fat, 18\% protein; Envigo). The caging contained Teklad diamond dry cellulose bedding (Envigo). Cages were changed weekly by transferring animals to clean cages. Hamsters were housed at a cage density of 2 hamsters per cage. The light cycle was $12 \mathrm{~h}$ of light/12 h of 
dark. Hamsters were monitored daily during the day. Hamsters were acclimated to the environment for 3 days prior to the study.

All manipulations were performed within a BSC. Animals were transported to the BSC within individual cages for all manipulations. Three- to 6-week-old golden Syrian hamsters were inoculated intranasally via both nostrils with $10^{5}$ PFU of SARS-CoV-2 in $100 \mu$ l Dulbecco phosphate-buffered saline (DPBS) ( $\mathrm{pH} 7.4$; Genesee Scientific). Hamsters were weighed and monitored for clinical signs of illness daily, including weight loss, lethargy, ruffled fur, or labored breathing. The mean weight for male hamsters was $68.3 \pm 8.9 \mathrm{~g}$, and the mean weight for female hamsters was $70.8 \pm 4.9 \mathrm{~g}$. Air samples, oral swabs, nasal washes, fur swabs, and rectal swabs were collected from each hamster daily. Nasal washes were collected by directly pipetting $50 \mu \mathrm{l}$ viral transport media $(1 \times$ M199 plus Hanks' salts [Sigma; catalog no. M9163], $0.005 \mathrm{M}$ Tris- $\mathrm{HCl}, 1 \%$ [wt/vol] bovine serum albumin, $2 \mathrm{mM}$ L-glutamine, 0.35g/liter sodium bicarbonate, $100 \mathrm{U} / \mathrm{ml}$ penicillin, $100 \mu \mathrm{g} / \mathrm{ml}$ streptomycin, and $1 \mu \mathrm{g} / \mathrm{ml}$ amphotericin B) into each nostril. Swab samples were collected by prewetting sterile flocked swabs (Puritan Medical Products; catalog no. 25-3306-H) in $500 \mu \mathrm{l}$ viral transport media, placing the swab inside the cavity, making 2 to 4 circular passes against the mucosal surfaces, immersing the swab in the viral transport media, and then freezing. Swabs and nasal washes were collected after air sampling while under isoflurane or ketamine/xylazine anesthesia, depending on whether the chamber or nosecone method was used (see "Particle sampling and measurement"). Hamsters were anesthetized by inhalation of $3 \%$ isoflurane or by intraperitoneal (i.p.) injection with a mixture of ketamine $(100 \mathrm{mg} / \mathrm{kg})$ and xylazine $(10 \mathrm{mg} / \mathrm{kg})$ until the animal was nonresponsive to a toe pinch. After sample collection, hamsters were monitored for recovery from anesthesia (resuming normal movement). All samples were frozen at $-80^{\circ} \mathrm{C}$ prior to testing. At the termination of studies, or when clinical signs of disease, such as $15 \%$ weight loss, were present, hamsters were euthanized via $\mathrm{CO}_{2}$ inhalation. Posteuthanasia, bronchoalveolar lavage (BAL) fluid was collected as previously described (36); whole lungs were also collected. Relative humidity and temperature in the animal facility during the studies were $27.1 \% \pm 11 \%$ and $24.6 \pm 0.8^{\circ} \mathrm{C}$, respectively.

Particle sampling and measurement. (i) Chamber and nosecone. Particles generated by hamsters were sampled using two different approaches. In the first, infected hamsters were placed in a 2-liter (3.75 in. by $9.00 \mathrm{in.}$ by $3.75 \mathrm{in}$.) sealed chamber (VetEquip) in which they were allowed to move freely. Clean air (Airgas; part no. OX USP300) was supplied from a PerkinElmer gas anesthesia system through an inlet to the chamber at a flow rate of 1.0 or 1.5 liter/min to match the flow rate of the equipment used to sample particles through an outlet (see section below). This approach captured total particles produced in exhaled breath, released from the fur, and resuspended from the chamber floor by the hamster's activity. The second approach captured particles produced in exhaled breath only. Infected hamsters were anesthetized with $100 \mathrm{mg} / \mathrm{kg}$ ketamine and $10 \mathrm{mg} / \mathrm{kg}$ xylazine. After the hamster was fully immobile, a nonrebreather nosecone (Kent Scientific; VetFlo-0802) was placed on the hamster. Air was provided through the nosecone's inlet tube, and particles were sampled via the outlet port.

(ii) Infectious virus collection. A water-based condensation particle sampler (Aerosol Devices Inc.; series 110A) was connected to the outlet of the chamber or nosecone. Superior to traditional methods for collecting infectious virus (37), this technique has been used to detect infectious SARS-CoV-2 in a hospital and car and directly in exhaled breath of patients $(7,9)$. The sampler was operated at 1.5 liter/ min for a total of $1 \mathrm{~h}$, collecting particles directly into a vial containing $400 \mu \mathrm{l}$ viral transport medium. To separate particles by size, an air sampling cyclone device (cyclone) (URG-2000-30E-5-2.5-S; URG, Chapel Hill, NC) that removes particles larger than $5 \mu \mathrm{m}$ at the sampling flow rate used here was installed upstream of the condensation sampler. Samples were collected for $30 \mathrm{~min}$ with the cyclone and $30 \mathrm{~min}$ without the cyclone. For 4 hamsters, the cyclone was used during the first 30-minute period, and for 4 hamsters, the cyclone was used during the second 30-minute period.

(iii) Particle size distribution. An aerodynamic particle sizer (TSI; model 3321) was connected to the outlet of the chamber or nosecone to measure the particle size distribution for $15 \mathrm{~min}$ in 1-min intervals at a flow rate of 1 liter/min, with makeup air provided at the same flow rate. This instrument detects particles across the size range of 0.5 to $20 \mu \mathrm{m}$. The first $2 \mathrm{~min}$ were discarded to prevent carryover between measurements. Background concentrations were measured in an empty chamber and nosecone to estimate the contribution from the hamsters alone and were subtracted from aerosol measurements.

Virus quantification. (i) Plaque assays. Infectious virus was quantified via Vero cell plaque assay. Briefly, samples were serially diluted 10 -fold, plated onto confluent Vero cells in a 6-well plate, and incubated for $1 \mathrm{~h}$ at $37^{\circ} \mathrm{C}$ to allow for viral adsorption. After the 1-h adsorption period, $2 \mathrm{ml}$ of an $0.8 \%$ (wt/ vol) agarose overlay medium was added to the wells. Plates were incubated for 1 day at $37^{\circ} \mathrm{C}$, after which a second 2-ml overlay containing 3\% neutral red was added to the wells. One day later, plaques were counted. The limit of detection was $5 \mathrm{PFU} / \mathrm{ml}$ for air samples, which were tested neat, and 50 PFU/ $\mathrm{ml}$ for all other samples, which were tested at a 1:10 dilution. This was converted to "per sample" to reflect the entire sample, as the volumes differed between sample type as follows: 25 PFU/swab (oral/ fur/rectal) and BAL fluid (500 $\mu \mathrm{l}), 2$ PFU/air sample (400 $\mu \mathrm{l})$, and 5 PFU/nasal wash (100 $\mu \mathrm{l})$.

(ii) Real-time RT-PCR. SARS-CoV-2 RNA was extracted from samples via Qiagen QIAamp viral RNA minikit. RNA was quantified by real-time reverse transcriptase PCR (RT-PCR) using the 2019-nCoV RUO primer/probe kit (IDT; catalog no. 10006713) and Bio-Rad iTaq universal probes one-step kit. Synthetic SARS-CoV-2 RNA (BEI, NIAID, NIH; NR-52358) was used for a standard curve. The limit of detection was 1.33- $\log _{10}$ RNA copies/oral swab, 1.66- $\log _{10}$ RNA copies/air sample, and 1.38- $\log _{10}$ RNA copies/nasal wash.

Statistics. Samples were compared using a mixed-effects analysis with Sidak's correction for multiple comparisons. All statistics were performed in GraphPad Prism 9. 


\section{SUPPLEMENTAL MATERIAL}

Supplemental material is available online only.

FIG S1, EPS file, $0.02 \mathrm{MB}$.

FIG S2, EPS file, 0.4 MB.

\section{ACKNOWLEDGMENTS}

Funding for this project was provided by a Virginia Tech Center for Emerging, Zoonotic, and Arthropod-borne Pathogens (CeZAP) seed grant, a Virginia Tech Institute for Critical Technology and Applied Science (ICTAS) Junior Faculty Award, and NIH NINDS R01NS124204. Support was also provided by the Virginia Tech Fralin Life Sciences Institute and the BIOTRANS Interdisciplinary Graduate Education Program.

We thank Amy Rizzo and TRACSS staff for contributions to the development of the animal protocol and animal husbandry.

\section{REFERENCES}

1. Marr LC, Tang JW, Van Mullekom J, Lakdawala SS. 2019. Mechanistic insights into the effect of humidity on airborne influenza virus survival, transmission and incidence. J R Soc Interface 16:20180298. https://doi .org/10.1098/rsif.2018.0298.

2. Morawska L, Johnson GR, Ristovski ZD, Hargreaves M, Mengersen $K$, Corbett S, Chao CYH, Li Y, Katoshevski D. 2009. Size distribution and sites of origin of droplets expelled from the human respiratory tract during expiratory activities. J Aerosol Science 40:256-269. https://doi.org/10.1016/j jaerosci.2008.11.002.

3. Prather KA, Marr LC, Schooley RT, McDiarmid MA, Wilson ME, Milton DK. 2020. Airborne transmission of SARS-CoV-2. Science 370:303-304. https:// doi.org/10.1126/science.abf0521.

4. Hinds WC. 1999. Aerosol technology: properties, behavior, and measurement of airborne particles. John Wiley \& Sons, Inc., New York, NY.

5. Wang CC, Prather KA, Sznitman J, Jimenez JL, Lakdawala SS, Tufekci Z, Marr LC. 2021. Airborne transmission of respiratory viruses. Science 373: eabd9149. https://doi.org/10.1126/science.abd9149.

6. Tang JW, Bahnfleth WP, Bluyssen PM, Buonanno G, Jimenez JL, Kurnitski J, Li Y, Miller S, Sekhar C, Morawska L, Marr LC, Melikov AK, Nazaroff WW, Nielsen PV, Tellier R, Wargocki P, Dancer SJ. 2021. Dismantling myths on the airborne transmission of severe acute respiratory syndrome coronavirus-2 (SARS-CoV-2). J Hosp Infect 110:89-96. https://doi.org/10.1016/j.jhin .2020 .12 .022 .

7. Lednicky JA, Lauzardo M, Hugh Fan Z, Jutla A, Tilly TB, Gangwar M. 2020. Viable SARS-CoV-2 in the air of a hospital room with COVID-19 patients. Int J Infect Dis 100:476-482. https://doi.org/10.1016/j.ijid.2020.09.025.

8. Santarpia JL, Rivera DN, Herrera VL, Morwitzer MJ, Creager HM, Santarpia GW, Crown KK, Brett-Major DM, Schnaubelt ER, Broadhurst MJ, Lawler JV, Reid SP, Lowe JJ. 2020. Aerosol and surface contamination of SARS-CoV-2 observed in quarantine and isolation care. Sci Rep 10:12732. https://doi .org/10.1038/s41598-020-69286-3.

9. Lednicky JA, Lauzardo M, Alam MM, Elbadry MA, Stephenson CJ, Gibson JC, Morris JG. 2021. Isolation of SARS-CoV-2 from the air in a car driven by a COVID patient with mild illness. Int J Infect Dis 108:212-216. https://doi .org/10.1016/j.ijid.2021.04.063.

10. Leung NHL, Chu DKW, Shiu EYC, Chan K-H, McDevitt JJ, Hau BJP, Yen H-L, Li Y, Ip DKM, Peiris JSM, Seto W-H, Leung GM, Milton DK, Cowling BJ. 2020. Respiratory virus shedding in exhaled breath and efficacy of face masks. Nat Med 26:676-680. https://doi.org/10.1038/s41591-020-0843-2.

11. Yan J, Grantham M, Pantelic J, Bueno de Mesquita PJ, Albert B, Liu F, Ehrman S, Milton DK, EMIT Consortium. 2018. Infectious virus in exhaled breath of symptomatic seasonal influenza cases from a college community. Proc Natl Acad Sci U S A 115:1081-1086. https://doi.org/10.1073/ pnas. 1716561115.

12. Milton DK, Fabian MP, Cowling BJ, Grantham ML, McDevitt JJ. 2013. Influenza virus aerosols in human exhaled breath: particle size, culturability, and effect of surgical masks. PLoS Pathog 9:e1003205. https://doi.org/10 .1371 /journal.ppat.1003205.

13. Tovey ER, Stelzer-Braid S, Toelle BG, Oliver BG, Reddel HK, Willenborg CM, Belessis Y, Garden FL, Jaffe A, Strachan R, Eyles D, Rawlinson WD, Marks GB. 2015. Rhinoviruses significantly affect day-to-day respiratory symptoms of children with asthma. J Allergy Clin Immunol 135:663-669.e12. https://doi.org/10.1016/j.jaci.2014.10.020.
14. Zhou L, Yao M, Zhang X, Hu B, Li X, Chen H, Zhang L, Liu Y, Du M, Sun B, Jiang Y, Zhou K, Hong J, Yu N, Ding Z, Xu Y, Hu M, Morawska L, Grinshpun SA, Biswas P, Flagan RC, Zhu B, Liu W, Zhang Y. 2021. Breath-, air- and surface-borne SARS-CoV-2 in hospitals. J Aerosol Sci 152:105693. https://doi .org/10.1016/j.jaerosci.2020.105693.

15. Ma J, Qi X, Chen H, Li X, Zhang Z, Wang H, Sun L, Zhang L, Guo J, Morawska L, Grinshpun SA, Biswas P, Flagan RC, Yao M. 2021. Coronavirus disease 2019 patients in earlier stages exhaled millions of severe acute respiratory syndrome coronavirus 2 per hour. Clin Infect Dis 72:e652-e654. https://doi.org/10.1093/cid/ciaa1283.

16. Edwards DA, Ausiello D, Salzman J, Devlin T, Langer R, Beddingfield BJ, Fears AC, Doyle-Meyers LA, Redmann RK, Killeen SZ, Maness NJ, Roy CJ. 2021. Exhaled aerosol increases with COVID-19 infection, age, and obesity. Proc Natl Acad Sci U S A 118:e2021830118. https://doi.org/10.1073/ pnas.2021830118.

17. Zhang C, Guo Z, Zhao Z, Wang T, Li L, Miao F, Zhang C, Li Y, Gao Y. 2021. SARS-CoV-2 aerosol exhaled by experimentally infected cynomolgus monkeys. Emerg Infect Dis 27:1979-1981. https://doi.org/10 .3201/eid2707.203948.

18. Sia SF, Yan L-M, Chin AWH, Fung K, Choy K-T, Wong AYL, Kaewpreedee $P$, Perera RAPM, Poon LLM, Nicholls JM, Peiris M, Yen H-L. 2020. Pathogenesis and transmission of SARS-CoV-2 in golden hamsters. Nature 583: 834-838. https://doi.org/10.1038/s41586-020-2342-5.

19. Chan JF, Zhang AJ, Yuan S, Poon VK, Chan CC, Lee AC, et al. 2020. Simulation of the clinical and pathological manifestations of Coronavirus Disease 2019 (COVID-19) in golden Syrian hamster model: implications for disease pathogenesis and transmissibility. Clin Infect Dis 71:2428-2446. https://doi.org/10.1093/cid/ciaa325.

20. Imai M, Iwatsuki-Horimoto $K$, Hatta M, Loeber S, Halfmann PJ, Nakajima N Watanabe T, Ujie M, Takahashi K, Ito M, Yamada S, Fan S, Chiba S, Kuroda M, Guan L, Takada K, Armbrust T, Balogh A, Furusawa Y, Okuda M, Ueki H, Yasuhara A, Sakai-Tagawa Y, Lopes TJS, Kiso M, Yamayoshi S, Kinoshita N, Ohmagari N, Hattori S-I, Takeda M, Mitsuya H, Krammer F, Suzuki T, Kawaoka Y. 2020. Syrian hamsters as a small animal model for SARS-CoV2 infection and countermeasure development. Proc Natl Acad Sci U S A 117:16587-16595. https://doi.org/10.1073/pnas.2009799117.

21. Lee AC-Y, Zhang AJ, Chan JF-W, Li C, Fan Z, Liu F, Chen Y, Liang R, Sridhar S, Cai J-P, Poon VK-M, Chan CC-S, To KK-W, Yuan S, Zhou J, Chu H, Yuen KY. 2020. Oral SARS-CoV-2 inoculation establishes subclinical respiratory infection with virus shedding in golden Syrian hamsters. Cell Rep Med 1: 100121. https://doi.org/10.1016/j.xcrm.2020.100121.

22. Rosenke K, Meade-White K, Letko M, Clancy C, Hansen F, Liu Y, Okumura A, Tang-Huau TL, Li R, Saturday G, Feldmann F, Scott D, Wang Z, Munster V, Jarvis MA, Feldmann H. 2020. Defining the Syrian hamster as a highly susceptible preclinical model for SARS-CoV-2 infection. bioRxiv https:// doi.org/10.1101/2020.09.25.314070.

23. Chan JF, Yuan S, Zhang AJ, Poon VK, Chan CC, Lee AC, Fan Z, Li C, Liang R, Cao J, Tang K, Luo C, Cheng VC, Cai JP, Chu H, Chan KH, To KK, Sridhar S, Yuen KY. 2020. Surgical mask partition reduces the risk of non-contact transmission in a golden Syrian hamster model for coronavirus disease 2019 (COVID-19). Clin Infect Dis 71:2139-2149. https://doi.org/10.1093/ cid/ciaa644. 
24. Adenaiye OO, Lai J, de Mesquita PJB, Hong F, Youssefi S, German J, Sheldon Tai SH, Albert B, Schanz M, Weston S, Hang J, Fung C, Chung HK, Coleman KK, Sapoval N, Treangen T, Maljkovic Berry I, Mullins K, Frieman M, Ma T, Milton DK, University of Maryland StopCOVID Research Group. 2021. Infectious SARS-CoV-2 in exhaled aerosols and efficacy of masks during early mild infection. Clin Infect Dis https://doi.org/10.1093/cid/ciab797.

25. Kutter JS, de Meulder D, Bestebroer TM, Lexmond P, Mulders A, Richard M, Fouchier RAM, Herfst S. 2021. SARS-CoV and SARS-CoV-2 are transmitted through the air between ferrets over more than one meter distance. Nat Commun 12:1653. https://doi.org/10.1038/s41467-021-21918-6.

26. Ong SWX, Tan YK, Coleman KK, Tan BH, Leo Y-S, Wang DL, Ng CG, Ng O-T, Wong MSY, Marimuthu K. 2021. Lack of viable severe acute respiratory coronavirus virus 2 (SARS-CoV-2) among PCR-positive air samples from hospital rooms and community isolation facilities. Infect Control Hosp Epidemiol:-6. https://doi.org/10.1017/ice.2021.8.

27. Johansson MA, Quandelacy TM, Kada S, Prasad PV, Steele M, Brooks JT, Slayton RB, Biggerstaff M, Butler JC. 2021. SARS-CoV-2 transmission from people without COVID-19 symptoms. JAMA Netw Open 4:e2035057. https://doi.org/10.1001/jamanetworkopen.2020.35057.

28. Subramanian R, He Q, Pascual M. 2021. Quantifying asymptomatic infection and transmission of COVID-19 in New York City using observed cases, serology, and testing capacity. Proc Natl Acad Sci U S A 118:e2019716118. https://doi.org/10.1073/pnas.2019716118.

29. Payton AJ, Forsythe DB, Dixon D, Myers PH, Clark JA, Snipe JR. 1993. Evaluation of ketamine-xylazine in Syrian hamsters. Cornell Vet 83:153-161.

30. Asadi S, Gaaloul Ben Hnia N, Barre RS, Wexler AS, Ristenpart WD, Bouvier NM. 2020. Influenza A virus is transmissible via aerosolized fomites. Nat Commun 11:4062. https://doi.org/10.1038/s41467-020-17888-w.

31. Peckham H, de Gruijter NM, Raine C, Radziszewska A, Ciurtin C, Wedderburn LR, Rosser EC, Webb K, Deakin CT. 2020. Male sex identified by global COVID-19 meta-analysis as a risk factor for death and ITU admission. Nat Commun 11:6317. https://doi.org/10.1038/s41467-020-19741-6.

32. Liu J, Ji H, Zheng W, Wu X, Zhu JJ, Arnold AP, Sandberg K. 2010. Sex differences in renal angiotensin converting enzyme 2 (ACE2) activity are 17beta-oestradiol-dependent and sex chromosome-independent. Biol Sex Differ 1:6. https://doi.org/10.1186/2042-6410-1-6.

33. Channappanavar R, Fett C, Mack M, Ten Eyck PP, Meyerholz DK, Perlman S. 2017. Sex-based differences in susceptibility to severe acute respiratory syndrome coronavirus infection. J Immunol 198:4046-4053. https://do .org/10.4049/jimmunol.1601896.

34. Dhakal S, Ruiz-Bedoya CA, Zhou R, Creisher PS, Villano JS, Littlefield K, Ruelas Castillo J, Marinho P, Jedlicka AE, Ordonez AA, Bahr M, Majewska N, Betenbaugh MJ, Flavahan K, Mueller ARL, Looney MM, Quijada D, Mota F, Beck SE, Brockhurst J, Braxton AM, Castell N, Stover M, D'Alessio FR, Metcalf Pate KA, Karakousis PC, Mankowski JL, Pekosz A, Jain SK, Klein SL. 2021. Sex differences in lung imaging and SARS-CoV-2 antibody responses in a COVID-19 golden Syrian hamster model. mBio 12:e0097421. https://doi.org/ 10.1128/mBio.00974-21

35. Rosenke K, Meade-White K, Letko M, Clancy C, Hansen F, Liu Y, Okumura A, Tang-Huau T-L, Li R, Saturday G, Feldmann F, Scott D, Wang Z, Munster V, Jarvis MA, Feldmann H. 2020. Defining the Syrian hamster as a highly susceptible preclinical model for SARS-CoV-2 infection. Emerg Microbes Infect 9:2673-2684. https://doi.org/10.1080/22221751.2020.1858177.

36. Sun F, Xiao G, Qu Z. 2017. Murine bronchoalveolar lavage. Bio Protoc 7: e2287. https://doi.org/10.21769/BioProtoc.2287.

37. Lednicky J, Pan M, Loeb J, Hsieh H, Eiguren-Fernandez A, Hering S, Fan $\mathrm{ZH}, \mathrm{Wu} \mathrm{C}-\mathrm{Y}$. 2016. Highly efficient collection of infectious pandemic influenza H1N1 virus (2009) through laminar-flow water based condensation. Aerosol Sci Tech 50:I-Iv. https://doi.org/10.1080/02786826.2016.1179254. 